\title{
Helping Students Create Their Own Books the Dialogic Way ${ }^{1}$
}

\author{
George M Jacobs \\ george.jacobs@gmail.com \\ HealthPartners.SG \\ Singapore, Republic of Singapore
}

\begin{abstract}
This article explores one technique that is consistent with the student-centered paradigm in language education: student-generated books. First, benefits of student-generated are discussed. Then, the article explores the crucial area of maintaining student ownership of their own books. The next topic explained in the article is why dialog is important as the students are developing their books. Finally, it is suggested that book creation works for students of all ages and levels, with examples given of students at the early childhood level and of second language students at university level.
\end{abstract}

Key words: Student-generated, student-centered, writing, dialogic, self-reliance, peer interaction

\section{Introduction}

In the teacher-centric paradigm, stusociety (Jacobs \& Farrell, 2001), such as the dents' designated roles mostly involve receiving. They receive, for example, teachers' explanations, teachers' instructions, teachers' and other education professionals' assessment instruments, and education materials developed by education professionals. In contrast, in the student-centric paradigm, students play more of a role in creating all of the above (Blumberg, 2016). These differences between teacher-centric and student-centric absence or presence of democratic structures in a country or other political unit. This article focuses on how students can create reading and other materials for themselves and peers. The article contains four parts: benefits of students creating their own books; student ownership of the books they create; the importance of promoting dialog during and after book creation; and which students should create their own books. education find similarities in the wider

\section{Benefits of Student-Created Books}

The term "create" a book is used instead of "write" a book to highlight that creating can often involve more than words, in particular visuals should often be added to promote visual literacy (Kiss \& Weninger, 2017). Additionally, book creators can include tactile features, e.g., pasting leaves into books, and sounds, e.g., making audio books and adding sound effects to online versions of books.

Book covers also offer space for exploring non-text communication.

Many benefits may accrue when students create their own books. These include: 1. Improves reading and writing skillsResearch supports that idea that the language skills of reading and writing, as well as listening and speaking, support one another and are usefully combined (Bromley, 1989;

\footnotetext{
${ }^{1}$ This article is accepted and will be published in Beyond Words Vol.8 No.1 May 2020. DOI: https://doi.org/10.33508/bw.v8i1.2354
} 
Grobe \& Grobe, 1977; Krashen, 1982; Sun, Yang, \& He, 2016).

2. Increases to use language -Sudirman \& Ati (2019) found that when students have more control over what they write, their desire to write increases.

3. Provides appropriate reading materialWhen books are created by students themselves, the books' topics are more likely to fit students' interests (Asaba \& Eidswick, 2018), and the difficulty level should be in the range of students' current proficiency level (Yano, Long, \& Ross, 1994). At the same time, even in the same class, student interests as to what to read and write differ based on many variables. For example, MerisuoStorm (2006) reported that in her sample of 10-11 year old Swedish students, while girls preferred adventure books, boys expressed more interest in comics and humorous books. Similarly, even in streamed classes, proficiency levels vary.

4. Demystifies books and authoring - It may be an exaggeration to say that students think books grow on trees or are produced by robots -the latter already happens (Poole, 2019) - but in the authors' experience, while most students, especially older students, have met people in many walks of life, they do not know any book writers, nor do they know about the book writing process.

5. Increases self-esteem-When students accomplish a task, such as creating a book (however simple that book might be) in a supportive setting, they receive positive feedback (although constructive criticism also has an important place) from teachers, peers, and perhaps others, such as family members, their self-esteem is likely to grow (Manning, 2007).

6. Builds observation skill-To create a book, students need to observe how books are constructed. In Gardner's taxonomy of multiple intelligences (Armstrong, 2018), observation skill can be considered part of naturalist intelligence.

7. Boosts organising skill-Creating a book also involves organizing skill, as students need to plan such aspects as the parts of the book's content, the visuals if any, how to bind the book if it is hard copy, and how to distribute the book. Of course, even with careful planning, creating a book often becomes a recursive process involving redoing and replanning various aspects (Abas, 2016). 8. Heightens communication skill- Students need to learn to avoid writer-based prose, i.e., writing that can be understood by the author, but not by others who lack the author's background knowledge. Instead, book creators need to communicate more effectively by asking themselves whether their books are reader-based, i.e., enough context has been provided (Ädel, 2017).

9. Strengthens self-reliance - rather than always depending on teachers and others, in keeping with the spirit of student-centered learning, students can generate some of their own materials (Allen, 1985).

10. Increases students' enjoyment of reading - Researchers have found that students involved in growing plant-based foods increase their consumption of such foods (e.g., Heim, Stang, \& Ireland, 2009). Perhaps, similarly, "growing" their own books may increase students' fondness for book reading.

11. Builds bonds between students and teachers-Teaching has been called a lonely profession, which seems paradoxical. How can teachers be lonely when all day we work surrounded by others: our students? However, teacher-centred instruction, with its emphasis on hierarchy, may tend to separate teachers from their students. At the same time, research suggests that loneliness poses a significant obstacle for students (Richardson, Elliott, \& Roberts, 2017). Development of Communities of Practice (Kevany \& 
MacMichael, 2014; Wenger, 1998) offers a student-centered approach that may overcome separation and loneliness. Communities of Practices build common interest and purpose among disparate groups of people, including students and teachers. Creating and sharing books offers activities with which communities canengage together.

\section{Student Ownership}

Students' felt ownership of the books they create lies at the heart of student-generated books. Without that feeling of ownership, book creation becomes just another teacher-centered activity, similar to doing worksheets. Thus, thought needs to be given to ownership issues that may arise; certainly, context will play a role in how teachers will address these issues.

Perhaps the most difficult issue teachers face in helping students create their own book involves the degree to which teachers should intervene in the process. For example, some students may have difficulty thinking of topics for their book. In such cases, teachers might want to use prompts, e.g., How many people in your family? or What is your favorite hobby? Also, models can be very useful. Students can use other books as models, varying them in such aspects as location, time, characters, and ending.

Also, on the matter of book topic, students should be able to change their minds whenever they wish. For instance, in the middle of writing a book, students can decide to abandon (temporarily or possibly forever) the specific book or even the idea of creating their own books. George was once helping his five-year-old neighbor write books. In the middle of one book, the author decided to switch from Ninjas to Princess Sophia. This right to change is similar to the right of students doing extensive reading to start reading one book and then change to another after deciding that the first book was, for whatever reason, not presently to their liking (Jacobs \& Farrell, 2012).

Probably the place where teachers feel the greatest temptation to intervene resides with the vocabulary and grammar of the book, although organization and formatting can also be issues. Student-generated books provide comprehensible input (Krashen, 1992) for the students and their peers. As a result, many teachers, as well as students and other stakeholders, do not feel comfortable unless they are confident that the vocabulary, grammar, and other language aspects reflect standard language usage. In contrast, other teachers believe that successive approximation (Hoskisson, 1975) may work, i.e., nonstandard forms can be accepted as part of the process of moving closer and closer to standard usage.

Also, even those who believe that teachers should intervene to help students achieve standard form in their books may postpone this intervention until later in the writing process, which designed to follow the recursive steps of prewriting, drafting, editing for content, and proofreading. Peers can be involved in these steps. Perhaps, peer intervention may be less threatening to students' feeling of ownership.

Ownership extends to areas beyond the content of the books. For example, students should decide how to hold their books' pages together, e.g., one student used one of her hair clips, but more typically, students use staples, or they punch holes and use string, or they have their books more professionally bound. Options for preserving the books include lamination and putting each page in an individual clear plastic sleeve. Of course, many online options also present themselves.

Other non-content issues with studentcreated books include whether to rewrite books to create neater versions and what 
should happen with finished books. One option for when students have completed their books is to create a class library, thereby making it easy for the students' present classmates, as well as future students to enjoy and learn from the books. Alternatively, students may want to take their creations home to show family members and friends or to be used as gifts. Again, the choice should probably remain with each book's creator.

\section{The Importance of Dialogue}

Vygotsky (1978) highlighted the importance of language in students' cognitive development. More specific to language learning, Long(2017) emphasized that interaction with peers and others promotes students' second language acquisition. Taking the above theoretical perspectives into account, Dialogic Reading (Doyle \& Bramwell, 2006) was developed to enhance a practice that has long been common among teachers of young students: reading aloud to their students. With Dialogic Reading teacher read aloud sessions become more interactive by sparking conversation on a wide range of possible topics, including social / emotional ones, and often connecting to students' lives. The same ideas used in Dialogic Reading also apply to the theme of the current article: helping students create their own books the dialogic way.

By emphasizing dialog, the book being read or created becomes just a tool for generating discussion, and while this discussion can touch on language matters, such as the choice of punctuation or tense, and comprehension, matters on which the teacher serves as authority figure, in keeping with studentcentered learning, a much wider range of topics are available. Because teachers and students are seen mostly as co-learners, discussions resemble those found in everyday settings with a preponderance of referential questions, i.e., questions for which the askers do not already know the answers, instead of display questions, i.e., questions for which the askers already know the answers (Farrell, 1999; Long \& Sato, 1983). An example of a display question might be, "What was the name of the sister in the story?," whereas a referential question could be, "Do you know anyone who is similar to the sister in the story, and, if so, how are the sister and the other person similar and different?" Display questions tend to dominate in teacher-centered classroom interaction.

Another aspect of the questions used to promote dialog compared to questions used in teacher-centered learning involves a focus on thinking questions (Degener\& Berne, 2017) rather than surface questions. With surface questions, students can often answer by merely going to the text and retrieving the answers from there, whereas with thinking questions, more elaborated thinking comes into play. An example on a surface question might be, "What room in the story has blue walls?", whereas a thinking question might be, "What is one thing in your bedroom that you do not need very much and might want to give to charity?"

Classroom dialog should extend beyond individual one-on-one student conversations with teachers. Student-student dialog should also take place, during all the recursive steps in the writing process. In this way, even if books are single-authored, the authors can acknowledge the contributions of others, just as often takes place with professionally published book. Students may need assistance in learning the skills involved in providing peer feedback (Min, 2016). Providing specific positive feedback is one such skill, e.g., instead of saying, "This is good," students might tell a classmate, "I really like all the colors you used in your drawing" or "I like the way that you help your parents." 


\section{Which Students Should Create Their Own Books}

Many different types of students can create their own books. For example, Pelton \& Pelton (2009) described how students created comic books as part of their mathematics studies. This next section of the paper looks at two groups of students creating their own books: early childhood students (3-8 years old) and teenage and young adult second language students. The content of these books is flexible, depending on the students' interests and purposes.

\section{Early Childhood Education}

Characteristics of early childhood students include that they may not be able to write at all, or they may need a great deal of help to write. Several ways exist to compensate for these students' lack of writing skill. One, they can use invented spelling (Martins, Salvador, Albuquerque, \& Silva, 2016). With invented spelling in an alphabetic language, students spell words in whatever way fits their understanding of sound-symbol correspondence. The latitude given to students to spell as they wish can go as far as students writing squiggles, as long as those squiggles have meaning to the students. A second way to compensate for students' current lack of writing proficiency involves someone else writing for the students. This writing could be done on a separate piece of paper from which students then copy into their book, or the helper could write directly into the students' books. Three, students can use a template from which they can copy many words, only writing the words needed to individualize their book. For instance, to help students create a book about their family, part of the template could go as follows, "There are people in my family. They are my mother, my father, my sisters, my brothers. Also, my lives with us." Students can delete the parts that are not relevant, e.g., if they are only children, students can delete the parts about sisters and brothers. These templates seem more compatible with teacher-centric education. However, the hope is that these templates represent a first step toward increasing student independence.

Another fairly unique characteristic of students in the early childhood years is their appreciation for visuals and their enjoyment in creating visuals. Indeed, many books written for these students feature a large drawing on each page accompanied by only a single sentence. Taking this emphasis on visuals over words even further, early childhood literature also includes wordless picture books (Grolig, Cohrdes, Tiffin-Richards, \& Schroeder, 2020). One advantage of this emphasis on visuals relates to the issue of student ownership; whereas teachers and other stakeholders may be loathe to allow student books to contain less than stellar language, most people accept a developmental view of students' art skills, possibly because the arts occupy a less valued place in the curriculum, especially as children near higher levels of education (Gregory, 2017). As a result, teachers who might readily intervene in students' language usage may be more willing to allow students complete ownership of the visuals they create.

\section{Teen and Young Adult Second Language Students}

Extensive reading plays a key role in many second language education programs. To do extensive reading, students require books at their independent reading level, i.e., the difficulty level at which students can understand the books with little or no external assistance, e.g., from dictionaries or peers. 
Most books in secondary school and university libraries, hard copy and online, are far above second language students' independent reading levels. Thus, graded readers, i.e., books specifically written or adopted to cater to second language learners at different levels of reading proficiency, were developed (Holster, Lake, \&Pellowe, 2017). Graded readers often come with a variety of accompanying activities(Mitchell, Snead, \& Walker, 2019).

Student-generated books have at least two advantages over the typical graded readers, which cost money to purchase and cater to international audiences. In contrast, books produced by second language students for themselves and their peers cost little (perhaps a fee for laminating or binding) or nothing, and students should have less difficulty understanding books created in their local context, although students need to be cognizant of producing reader-based texts, e.g., in the case of students from Iran doing books about their home context in a multinational class with classmates from countries such as India, Japan, and Spain.

Books appropriate for early childhood students may not be appropriate for older students. For instance, teen and young adult students may be likely to reject as childish books that consist of pages with a large drawing and only a single sentence. Also, while books of five-six pages may satisfy young students, older students may want to produce longer books. One method that the authors of this article have used with older students involves producing anthologies in which each student takes responsibility for one page. For example, each student can write for an anthology entitled, "A Scary Moment." Teachers can also contribute to the anthology with an entry of their own, or they can find a model by a professional author or a former student. Rather than only distributing the model to students, teachers might want to spend time facilitating students' appreciation of salient features of the model (Sowell, 2019).

As mentioned earlier, dialog can be useful at all stages of the writing process. Furthermore, students can dialog in order to share how they created their books with dialog prompts such as, "What is your favorite part of the story and why do you like it?" or "What was some useful feedback you received, and did you change your story because of the feedback?" Other opportunities for dialog can arise after peers have read each other's stories. Here, students can write their own discussion questions to accompany their stories (Song, Oh, \&Glazewski, 2017).

In addition to anthologies, another type of student-generated book for second language students arises out of a well-known education practice: dialog journals (Mukti, 2016). With dialog journals, students write regularly in a paper notebook or on an electronic device. Journal entries can be based on the entire class responding to the same prompt, or each student can base their entry on whatever inspires them at the time. The dialog in dialog journals comes into play as each journal entry receives a response from peers, teachers, or others. Over the course of a term, students' books will have grown large with many journal entries, each with one or more responses. While students may not wish to share their dialog journals widely, perhaps these books can serve as a way to encourage students to reflect on their own thoughts, thereby mobilizing their intrapersonal intelligence (Armstrong, 2018).

\section{Conclusion}

This article has suggested one method of inspiring more student-centeredness: student-created books. Student ownership of their books deserves highlighting, as in the 
experience of the article's authors, establishing student ownership constitutes a key potential stumbling block. The book creation process is impoverished without it. Furthermore, a vital aim of student-centered education is to encourage students to become lifelong learners. Whereas teacher-centered instruction risks draining education of the joy and excitement inherent in learning, studentcentered pedagogy offers the promise of a citizenry keen to learn throughout life and, just like students may share the books they create, we hope people throughout their lives will share their learning in a host of varied ways.

\section{(C) Jacobs, George M.}

Dr George M Jacobs writes and speaks on such topics as education, environment, health, and animal welfare. Many of his papers can be found at www.georgejacobs.net. His forthcoming book, with Thomas Farrell, is the second edition of Essentials for Successful English Language Teaching to be published by Bloomsbury

\section{References}

Abas, H. (2016). Indonesian EFL students' perspective on writing process: A pilot study. Advances in Language and Literary Studies, 7(3), 21-27.

Ädel, A. (2017). Remember that your reader cannot read your mind: Problem/solution oriented metadiscourse in teacher feedback on student writing. English for Specific Purposes, 45, 54-68.

Alhammad, R., \& Ku, H. Y. (2016). Graduate students' experiences and attitudes toward using e-books for college-level courses. Journal of Educational Research and Innovation, 5(2), 1-16. Retrieved from https://digscholarship.unco.edu/cgi/viewcontent.cgi?articl026\&context=jeri

Allen, J. (1985). Factors influencing the readability of student-generated texts. ((ERIC Document Reproduction Service No. ED 257 038).

Armstrong, T. (2018). Multiple intelligences in the classroom (4 ${ }^{\text {th }}$ ed.). Alexandria, VA: Association for Supervision and Curriculum Development.

Asaba, M., \&Eidswick, J. (2018). The effect of topic interest and choice in second language journal writing. Writing \& Pedagogy, 10(1-2), 161-190.

Blumberg, P. (2016). Assessing implementation of learner-centered teaching while providing faculty development. College Teaching, 64(4), 194-203.

Bromley, K. D. A. (1989). Buddy journals make the reading-writing connection. The Reading Teacher, 43(2), 122-129.

Degener, S., \& Berne, J. (2017). Complex questions promote complex thinking. The Reading Teacher, 70(5), 595599.

Doyle, B. G., \& Bramwell, W. (2006). Promoting emergent literacy and socialemotional learning through dialogic reading. The Reading Teacher,59(6), 554-564.

Farrell, T.S.C. (1999). Reflective teaching: A case study. Asian Journal of English Teaching, 9, 105-114.

Gregory, D. (2017). Let's get rid of art education in schools. Phi Delta Kappan, 98(7), 21-22.

Grobe, S. F., \&Grobe, C. H. (1977). Reading skills as a correlate of writing ability in college freshmen. Literacy Research and Instruction, 17(1), 50-54. 
Grolig, L., Cohrdes, C., Tiffin-Richards, S. P., \& Schroeder, S. (2020). Narrative dialogic reading with wordless picture books: A cluster-randomized intervention study. Early Childhood Research Quarterly, 51, 191-203.

Heim, S., Stang, J., \& Ireland, M. (2009). A garden pilot project enhances fruit and vegetable consumption among children. Journal of the American Dietetic Association, 109(7), 1220-1226.

Holster, T. A., Lake, J. W., \&Pellowe, W. R. (2017). Measuring and predicting graded reader difficulty. Reading in a Foreign Language, 29(2), 218-244.

Hoskisson, K. (1975). Successive approximation and beginning reading. The Elementary School Journal, 75(7), 443451.

Jacobs, G. M. (2014). Selecting extensive reading materials. Beyond Words, 2(1), 112-127. Retrieved from https:// files.eric.ed.gov/fulltext/ED574001.pdf

Jacobs, G. M., \& Farrell, T. S. C. (2001). Paradigm shift: Understanding and implementing change in second language education. TESL-EJ, 5, 1-9. Retrieved from http://www.tesl-ej.org/wordpress/ issues/volume5/ej17/ej17a1

Jacobs, G. M., \& Farrell, T. S. C. (2012). Teachers sourcebook for extensive reading. Charlotte, NC: Information Age Publishing.

Kevany, K. M., \&MacMichael, M. (2014). Communities of knowledge and knowledge of communities: An appreciative inquiry into rural wellbeing. Gateways: International Journal of Community Research and Engagement, 7(1), 34-51. doi:10.5130/ijcre.v7i1.3392

Kiss, T., \&Weninger, C. (2017). Cultural learning in the EFL classroom: The role of visuals. ELT Journal, 71(2), 186-196.
Krashen, S. D. (1982). Principles and practice in second language learning. New York, NY: Pergamon.

Long, M. H. (2017). Problems in second language acquisition. New York, NY: Routledge.

Long, M. H., \& Sato, C. (1983). Classroom foreigner talk discourse: Forms and functions of teachers' questions. In $\mathrm{H}$. Seliger, H., \&M. H. Long (Eds.), Classroom oriented research in second language acquisition(pp. 268-286).Rowley, MA: Newbury House.

Manning, M. A. (2007). Self-concept and self-esteem in adolescents. Student Services, 2, 11-15.

Martins, M. A., Salvador, L., Albuquerque, A., \& Silva, C. (2016). Invented spelling activities in small groups and early spelling and reading. Educational Psychology, 36(4), 738-752.

Maslow, A. H. (1943). A theory of human motivation. Psychological Review, 50(4), 370-396.

Merisuo-Storm, T. (2006). Girls and boys like to read and write different texts. Scandinavian Journal of Educational Research, 50(2), 111-125.

Min, H. T. (2016). Effect of teacher modeling and feedback on EFL students' peer review skills in peer review training. Journal of Second Language Writing, 31, 43-57.

Mitchell, C., Sneath, R., \& Walker, R. J. (2019). Notes on introducing a standardised extensive reading program: First performance and initial expectations. Reitaku University Journal, 102, 79-93.

Mukti, A. (2016). The effectiveness of dialogue journals in improving the skill in writing narrative texts. IJEE (Indonesian Journal of English Education), 3(1), 1-14. 
Pelton, L. F., \& Pelton, T. (2009, June). The learner as teacher: Using student authored comics to "teach" mathematics concepts. In EdMedia+ Innovate Learning (pp. 1591-1599). Waynesville, NC: Association for the Advancement of Computing in Education (AACE).

Poole, S. (2019, March 25). The rise of robot authors: is the writing on the wall for human novelists? The Guardian.

Retrieved from https://www.theguarian.com/books/ 2019/mar/25/the-rise-of-robot-authorsis-the-writing-on-the-wall-for-humannovelists

Richardson, T., Elliott, P., \& Roberts, R. (2017). Relationship between loneliness and mental health in students. Journal of Public Mental Health, 16(2), 48-54.

Song, D., Oh, E. Y., \&Glazewski, K. (2017). Student-generated questioning activity in second language courses using a customized personal response system: a case study. Educational Technology Research and Development, 65(6), 14251449.
Sowell, J. (2019). Using models in the second-language writing classroom. English Teaching Forum, 57(1), 2-13.

Sudirman, S., \&Ati, S. (2019). The use of blogs to enhance students' writing motivation. LANGUA: Journal of Linguistics, Literature, and Language Education, 2(1), 39-44.

Sun, Z., Yang, X. M., \& He, K. K. (2016). An extensive reading strategy to promote online writing for elementary students in the 1: 1 digital classroom.

Computer Assisted Language Learning, 29(2), 398-412.

Vygotsky, L. S. (1978). Mind in society (ed. by M. Cole, V. John-Steiner, S. Scribner, \& E. Souberman). Cambridge, MA: Harvard University Press.

Wenger, E. (1998). Communities of Practice: Learning, meaning, and identity. Cambridge, United Kingdom: Cambridge University Press.

Yano, Y., Long, M. H., \& Ross, S. (1994). The effects of simplified and elaborated texts of foreign language reading comprehension. Language Learning, 44(2), 189-219. 